\title{
Analysis of factors that predict clinical performance in medical school
}

\author{
Casey B. White $\cdot$ Eric L. Dey $\cdot$ Joseph C. Fantone
}

Published online: 5 August 2009

(C) Springer Science+Business Media B.V. 2009

\section{Erratum to: Adv in Health Sci Educ \\ DOI 10.1007/s10459-007-9088-9}

The category should read:

ORIGINAL PAPER.

The online version of the original article can be found under doi:10.1007/s10459-007-9088-9.

C. B. White $(\bowtie) \cdot$ J. C. Fantone

University of Michigan Medical School, 1135 E. Catherine St. 3960 Taubman Medical Library, Ann Arbor, MI 48109-5726, USA

e-mail: bcwhite@umich.edu

\section{E. L. Dey}

University of Michigan School of Education, Ann Arbor, MI, USA 